\title{
TOMMY BOLIN: THE DEVELOPMENT CRISES OF PROFESSIONAL MUSIC CAREER AND RAGGED PATH IN LIFE AS AN OBJECT OF PHILOSOPHICAL AND CULTUROLOGICAL RESEARCH
}

Annotation. The object of the study are to overcome the problems of psychological stress in a professional music career. Bolin's Music is elegant and it is characterized by a combination of strength and exquisite beauty. As a pioneer in working with sound, it is still at a young age has won recognition among jazz and rock musicians. It was Tommy Bolin was able to fully refresh the creative atmosphere of DEEP PURPLE, that by the time a kind of stubborn self-copying regressed, although he could not prevent the collapse of the group. His death left a void in certain unique sector of rock music that represents musical cocktail of a mixture of jazz, hard rock and vintage blues. In this arlicle author suggested and tried to justify the assumption that a great musician, perhaps one of the most prolific and underrated guitarists of all time - Tommy Bolin has become hostage to the brand, created originally for the realization of other ideas of another remarkable musician Ritchie Blackmore. Presented version according to which these and other circumstances were the main determinants of psychological crisis of professional musical activities that are the subject of philosophical and cultural urological research The research based on the phenomenological concept of organizational culture and the theory of social institutions, which are understood as stable complexes of formal and informal rules, principles, norms, attitudes governing the interaction of people in a particular sphere of life and organizes it into a system of roles and statuses. The novelty of the research lies in the scientific substantiation of the reasons for the crises of professional music career, Tommy Bolin, which ultimately led to a life of tragedy - the death of the great guitarist. Over the past year and a half life of Tommy Bolin was four errors - brand (first), communicative (two), psychological (third) and operational (fourth), the totality of which played a fatal role.

Keywords: Record Company, Album, Live Performance, Guitarist, Rock Musician, DEEP PURPLE, Tommy Bolin, Brand, Music Industry, Version of Events.

The filophone interaction between people is generated and maintained by making typical the circumstances of communication in this field (code of conduct). The development and adoption of collective norms are the result of typing the content of mental states of filophone-men and music fans. So melomania in its communication content is a special type of the filophone communication (a social interaction of collectors), where the main communicative tool supports collecting (as an active action).

The study of different types of objects phonograms at different times was carried out by such outstanding domestic scientists as J. Avramenko, O. Boyarchuk, V. Dozortsev, K. Zvehyntseva, A. Sergeev, A. Stepanova, A. Frolov, H. Yarkin et al. With modern scholars should note G. Vlasov, N. Goncharov, A. Kasyanov, G. Kwiatkowskij, N. Komarov, I. Nabokov, I. Novikova, I. Saltanovych, A. Tuhusheva, M. Capko, I. Czyzhova others. However, in the scientific literature, the problem of record collectors (filophone) communication is poorly studied both in theoretical and practical aspects. Nowadays so far we do not know thorough comprehensive study of the phenomenon of collecting from the standpoint of psychology, sociology, history, cultural, museum studies and law. There are no studies of this problem from the perspective of social communication.

Studying a creative way and DEEP PURPLE's heritage of interest to many researchers - audiophiles' gathering (filophonists, record collectors etc.), journalists, writers and scientists (cultural studies and musicologists). Among researchers should mention, first of all, foreign authors such as - Geoff Barton, Mel Brown, Jeff Burger, Greg Prato, John Herdt, Peter Cresenti, Keith A. Gordon, James Halbert, Bill Harper, Chris Jisi, Mark Bosch, Joel McIver, Simon Robinson, Jesse Russell, Ronald Cohn, Eric Smets, Charles M. Young, Gil Asakawa, Dave Tompson, as well as Russian and Ukrainian - Alexander Galin, Vladimir Dribuschak, Sergey Korotkov, Vladimir Impaler, Natalia Chorina and others. However, a profound scientific research on the causes of events 1975-1976's there, and tragedy of the 
guitarist Tommy Bolin, is considered mainly with only one point of view (drug addiction).

Although it is a recent interest in the work of Tommy Bolin is enhanced thanks to the work on the reissue of phonographic heritage of this unjustly forgotten musician.

Tommy Bolin is one of the most brilliant and underrated musicians of the twentieth century! Tommy's story is an all too familiar rock and roll tragedy in the same way as those of Paul Kossoff, Phil Lynott, Gary Thain..., and a host of others ${ }^{[1]}$. Tommy Bolin burst upon the mid-seventies scene like a ball of fire, bringing jazz inventiveness to the heavy metal style. Just as quickly, it seems, the flame was out, but the afterglow is still with us. Tommy Bolin in retrospect, was a pioneer of today's indemand style of versatile rock guitar musicianship ${ }^{[2]}$.

Tomas Richard Bolin was born on August 1, 1951, in Sioux City, lowa, the USA. He died on December 4, 1976. A combination of power and exquisite beauty characterizes his music. Being a pioneer in working with sound, Tommy did different tonal guitar experiments and at a very young age he had won recognition among jazz and rock musicians. It was a persistent search a «corporate» sound. Musical kaleidoscope of Tommy Bolin combined air, delicate melodies, as well as it filled with swirling, dense energy hard rock adventure films, Latin American motifs, funky rhythm and jazz improvisation... This incredible rock cocktail formed solid, instantly recognizable style of the guitar maestro.

To many, Tommy Bolin was the legitimate heir to Jimi Hendrix's rock guitar throne. Stints with the JAMES GANG and DEEP PURPLE - as well as solo albums and a groundbreaking release with jazz-rocker Billy Cobham - certainly proved that the adulation was rightly deserved. And with a techno-color fashion sense, he certainly stood out from the pack ${ }^{[3]}$.

Commenting on the circumstances, causes and reasons of the tragic departure of the remarkable guitarist, having analyzed the strategies of rock industry, we have no right to assert any culpability of concrete individuals. We emphasize that the subject of documentary and journalistic analysis in our case was not the «classic» criminalistic tracks. Briefly our version can be formulated as follows: the death of Tommy Bolin in 1976 is the logical outcome of branded error made by label The Purple Records in 1975. When Tommy Bolin replaced Ritchie Blackmore as guitarist of DEEP PURPLE, hardly anyone could have predicted the dramatic consequences of this «incommensurate castling» ${ }^{[4]}$. Thus, the new atypical version of the events of the past, based on analysis of the facts collected by us is presented to the readers' attention.

Already at the age of thirteen Tommy came to the door of a big rock. He spent his childhood there, and with his family interested in music to some degree, soon got the bug himself - his interest becoming more positive once he'd seen Elvis and his contemporaries on a TV show. At 13, he decided to take up drumming, though once he discovered how much a full kit would cost he began experimenting with both keyboards and the guitar, eventually settling for the latter as it was the cheapest of the three (though he continued to play drums as a hobby all his life, saying later it had been a good way of strengthening his wrists for the guitar) ${ }^{[5]}$.

Tommy's high school days seem to have been one long feud with various kinds of authority - he wanted to learn music and school didn't teach it.

After being kicked out of high school in Sioux City, lowa, in 1967 for refusing to cut his hair, Bolin drifted to Denver where he established a reputation as a silky guitar stylist and gutsy vo calist on two albums cut with ZEPHYR ${ }^{[6]}$. Tommy Bolin began his professional career in 1967 in Denver with a group CROSSTOWN BUS, almost immediately renamed as AMERICAN STANDARD. But the official studio recordings were not created during one year of this collaboration. There were no legitimate releases of Tommy Bolin's performances with the group THE GOOD RATS. For the first time listener could meet the technique of improvisation of this lead-guitarist on the album Zephyr, recorded by U.S. hard-blues group ZEPHYR in 1969. Two albums later they drifted apart due to various reasons, including the frustration of not being able to take the band to the next level ${ }^{[7]}$.

In 1971 Tommy Bolin decided to move to more advanced projects and founded the fusion-jazz-rockblues group ENERGY, which included Jeff Cook, Stanley Sheldon, Bobby Berg, Tom Stephenson and Gary Wilson. Their material is a powerful vocal-oriented jazz-rock with a strong psychedelic accent. However, the official CD of this project never saw the light.

In May 1973 Tommy returned to New York to help record Billy Cobham's seminal Spectrum album. Cobham had left THE MAHAVISHNU ORCHESTRA earlier in the year, coinciding with the end of ENERGY, and chose Tommy to play on the sessions, remembering his performances on Jeremy Steig's 1971 New York demos ${ }^{[8]}$.

From August 1973 to August 1974 Bolin as a guitarist, vocalist and main songwriter JAMES GANG was involved in recording albums Bang and Miami. There, he wrote or co-wrote most of the material for the band's 1973 release, Bang, as well as their 1974 follow-up, Miami. He also supplied his first recorded lead vocals on "Alexis», his own composition ${ }^{[2]}$. Such hits as "Standing In The Rain», «Alexis», «Red Skies», "Spanish Lover» and others became a visiting card of Tommy and this rock band ${ }^{[9]}$. By the way, after carefully listening to these releases JAMES GANG with Tommy 
Bolin appears parallel with Come Taste the Band, which confirms the idea who was the main composer in the latter case.

After leaving the JAMES GANG at the end of August, 1974 Tommy Bolin returned to Colorado and attempted to form a band with Mike Finnigan on vocals and keyboards and Stanley Sheldon on bass. That project folded and by the end of December Tommy and Stanley had both moved to Los Angeles in search of opportunities. There they met keyboardist Ronnie Barron who was a friend of Dr. John (the Night Tripper), which lead to Tommy and Stanley recording tracks with Dr. John for what would become the Hollywood Be Thy Name album ${ }^{[10]}$, released October 6, 1975. By the way names Sheldon and Bolin in personnel on this disc is not specified.

While working in JAMES GANG Tommy was invited by the famous jazz musician and arranger Billy Cobham to participate in the recording of Spectrum, which was released in October 1973 under the name major-label «Atlantic Records». The guitars of the Spectrum made the record the most impressive album of a super-drummer who demonstrated the skill of the young Bolin.

The Billy Cobham's LP Spectrum, issued in October 1973, not only established itself as one of the definitive jazz-rock albums of the time, but also introduced Bolin's playing to a far wider audience ${ }^{[5]}$. His guitar work can be heard on all but two tracks ${ }^{[11]}$.

With JAMES GANG floundering a bit past their due date at this point, Tommy left the band and for a short time did session work contributing a few guitar tracks to Canadian 70s hard rockers MOXY on their debut album ${ }^{[7]}$.

In December 1974, Tommy Bolin took part in the recording of the album of another jazz drummer Alphonse Mouzon - Mind Transplant, recorded by the American jazz-oriented recording company «Blue Note» ${ }^{[12]}$. The release came out at the beginning of 1975. The album with Mouzon, called Mind Transplant has been regarded as «one of the best fusion recordings of all time» ${ }^{[7]}$.

For less than nine years of work — from 1967 to 1976 - Tommy Bolin left some official studio releases: two LP with the Denver group ZEPHYR, which was one of the best teams that played a hell mix of psychedelic, blues, jazz and hard rock JAMES GANG and the ensemble from Cleveland, one album — with Billy Cobham, Alphonse Mouzon and DEEP PURPLE, and as a special guest in the first album of the Canadian group MOXY (1975), on which Bolin guitar solo can be heard on six out of the eight tracks.

In spring of 1975 Tommy Bolin as a solo performer, finally signed a contract with the label «Atlantic» to record and release his first full album Teaser. In music community Bolin appears on this record as a highly original composer, poet, philosopher, competent arranger, highly technical guitarist, singer and a nice decent organist. By the way, the album Teaser is considered to be the highest point in his amazing but short career. By the time of the appearance of this release, Tommy was in the ranks of DEEP PURPLE. In 1975 he was approached by DEEP PURPLE to replace Ritchie Blackmore for the Come Taste the Band album and subsequent tour ${ }^{[13]}$. His performances confirmed his reputation as one of the most exciting, up and coming rock guitarists. His solo albums Teaser (1975) and Private Eyes (1976) also help underline this claim ${ }^{[1]}$.

Someone names Mk IV «the darkest period of PURPLE». But this is not true. After the departure of Blackmore, being supported by Hughes Coverdale opposed the termination of DEEP PURPLE. As a member of DEEP PURPLE, Bolin was pushed into the limelight, resulting in countless comparisons to Blackmore and speculation as to whether he would continue his solo career ${ }^{[2]}$.

Till nowadays, the common view among the domestic and foreign authors in the evaluation of phonographic creative of Tommy Bolin's heritage is not reached.

We'll specify that it was not Glenn Hughes who insisted on taking Bolin in the group, he had already started to make friends with him, but Coverdale, before he came to DEEP PURPLE in 1973, first heard Tommy Bolin's guitar on Billy Cobham's album Spectrum. David, who was captured by Bolin's jazz-rock guitar, has attracted Lord's interest to the new applicant for the vacant position of lead guitarist before starting «Live» listening. As acknowledged by Coverdale, Bolin was the third in his list. Tommy Bolin was officially invited to become a member of DEEP PURPLE immediately without any expectations and thoughts during the first listening. The decision to accept Bolin was taken spontaneously after his first chords. At this time Tommy was still working in the studio «Trident Studios» with the best studio musicians (eg, including GENESIS drummer Phil Collins) to create a Teaser ${ }^{[14]}$.

Come Taste the Band and Teaser were released virtually simultaneously — in November 1975. They felt a strong influence of Bolin on the disc, Come Taste the Band, he acted as the original guitarist with his own style, as well as a competent composer, who took part in the composition of seven out of the ten songs. On Come Taste the Band Tommy showed himself as a vocalist. Particularly, his voice can be heard in the performance of the self-passage of the composition «Dealer». In addition, Tommy had to play more instead of Hughes and bass in "Gettin' Tighter». David Coverdale still considers the work of Tommy in Come Taste the Band is remarkable, and Glenn Hughes agrees that Tommy played various jam sessions stunningly, but still he could not come up with metal riffs. And although David finally spoiled 
relations with Hughes, during their work in the album Coverdale took an active part in the composition of the new material, becoming a co-author of seven out of the nine songs placed on the disc. Moreover, he is convinced that the drive corresponds to the traditional canons of DEEP PURPLE.

Jon Lord admitted that, in fact, due to his powerful energy Tommy Bolin breathed the life into DEEP PURPLE. However, the great maestro (June 9, 1941 July 16,2012 ) to his last days, thought that LP Come Taste the Band is the album of Tommy Bolin, Glenn Hughes and David Coverdale, and not of the full-DEEP PURPLE, that's why this release can not be regarded as an official album of DEEP PURPLE. Paice also questioned whether they had the right to be considered as DEEP PURPLE at that time, but the record label insisted on it. Therefore, if not for the stubbornness of a management of the own record label «Purple Records», a large rock history would have lost one, half genius, half mad and fiercely criticized during 37 years, the DEEP PURPLE's album, but instead of it there would be a only new trial album of Britain-American hardfusion group (there were even variations of its name suggested Coverdale — GOOD COMPANY, PURPLE and THE DEEPS). Theoretically, this new project which consisted of Coverdale, Hughes, Lord, Bolin, Paice could be declared as a successor of DEEP PURPLE, but it was taken in front of audience as a new brand, i.e. under a new name (stylistically similar or including one of the two words of the original brand). However, to the great disappointment of Coverdale his proposal to change the name of the group was not supported, and eventually it was decided for commercial reasons to keep already «unpromoted» title DEEP PURPLE.

By the way, Tommy a little bit, «schlocked» using their old billets. For example, the theme of «Gettin' Tighter» was one of April session in Denver, 1971, and «Love Child» was of the May «Spectrum» sessions in 1973 with Billy Cobham, which, for some reason, he rejected for his solo work as well as «Lady Luck» that he played in his performances for four years but it required some refinements... By the way, the «audiopirates» released a double-disc by Tommy Bolin Spectrum Session (Love Child), where you can hear the outline of some topics of the future Come Taste the Band. Thus, to tell the truth the main creative priorities in preparation of the album were done by Bolin, Coverdale and Hughes was only the third. Tommy even said that to work with David was very magnificent, and for the next album, he might write more music with Glenn. The real work was with a hard worker Coverdale, and with Hughes they had mainly future plans.

In the album Come Taste the Band much more free and relaxed atmosphere prevails, compared with some previous studies of DEEP PURPLE, but it was met by the press initially categorically and cold and even PR-statement about Bolin as «The Best Young Guitarist of the World» did not help. In fact, by this time he had another kind of the title «Best Replacement Guitarist» ${ }^{[15]}$.

Nevertheless, he was willing to experiment with the aim of bringing a special mood or feeling in the old rock formula is one of the main things to set him apart from most other guitarists.

"Between the Purple and the solo stuff», Tommy Bolin concludes, exuding an enthusiasm that convincingly underlines his words, «I couldn't be happier. I feel I can finally try all the things I've always wanted to do. It's like a new lease on life» ${ }^{[16]}$.

On November 8, 1975 the fourth touring of DEEP PURPLE began on the promotion of the new album in Honolulu (the Hawaiis). Repertoire consisted of five new songs: «Lady Luck», "Gettin' Tighter», «Dealer», «Love Child», «This Time Around», two songs compositions Mk II («Space Truckin'» and «Smoke On The Water») and Mk III («Burn» and «You Fool No One»), a song from a Bolin's solo album (by Tommy's own choice - «Wild Dog», «Marching Power» and «Homeward Strut»); "Highway Star» was commonly performed for the encore. Tommy Bolin also claimed some vocal parts. And it was the development and innovations, formed on the Burn and Stormbringer, - as the unsurpassed harmony the duo Coverdale \& Hughes.

But gradually, the tour ran into trouble. It was not easy for Tommy because the audience chanted «Ritchie, Ritchie!». He was being a little arrogant, and sometimes he was angry, lost clarity and could not show his talent for music. The group members was not ready for such an active rejection of Tommy Bolin by Ritchie Blackmore's fans. They demanded Blackmore on stage! Lord was struck unpleasantly by the reaction not only of European fans but the U.S. as well because Bolin was their compatriot.

However, it should be admitted that during the concert it often happened Tommy drew the audience to his side: he was a great guitarist. Tommy had so bright talent when he was at his best. Bolin's rhythm and space were just amazing, and in the «live» performances he wanted to bring an element of brightness on the stage as an alternative to the reserve of a «dark and incomprehensible king of a hard rock guitar». Unfortunately, Tommy had to urge himself constantly by drugs. By 1975, Tommy Bolin had not been a complete addict. He used cocaine a little like most rockers of the time. But since the end of autumn 1975 everything became worse by the tight tour schedule of the group, when a young and talented, smiling guy who achieved a very serious success in a short time without any assistance and he was a complete opposite of Ritchie. Every day he had to transform into a «dark and inscrutable king of a hard rock guitar». He, like any selfsufficient person, did not like such a duality. And it was 
notorious that the loyal assistant of such reincarnation remained heroin ${ }^{[16]}$. The person who made Tommy an addict was not known. But the only thing is clear: before joining DEEP PURPLE Bolin didn't use heroin, and after the collapse of the group in March 1976 Tommy couldn't stop the progressing drug addiction.

Perhaps all of this couldn't happen under any other name. Who knows? But the rock history, like any other story, does not tolerate the subjunctive mood.

After the collapse of DEEP PURPLE Tommy immediately returned to the States to record his second solo album, Private Eyes, released September 1976. He then went on the road to promote the album with a rotating cast of players which included Narada Michael Walden, Mark Stein, Norma Jean Bell, Reggie McBride and Jimmy Haslip ${ }^{[17]}$.

Before the concert, Bolin tells a friend the tour will be «the biggest thing I've ever done». It's also the last thing he'll ever do ${ }^{[18]}$.

By the Private Eyes album contains some sensational music, but there are additional reasons why it holds a special place in the Tommy Bolin story. Whereas Teaser drew on session players, Private Eyes utilised the «official» THE TOMMY BOLIN BAND. The album version was reportedly edited down from a take lasting almost twice as long. If the master-tape still exists, it would be wonderful to hear that unpruned version ${ }^{[19]}$.

Official Tommy Bolin's lifetime discography includes eight vinyl releases one of them is post-mortem. They are all very different. He wrote 33 songs in four main albums. However, there were remained an incredible amount of unrealized and extremely rare archival Bolin's records and groups in which he played.

The phonograph prints of Tommy Bolin in formal and informal recording still remain under-researched issues. Moreover, his work studying in the informal record is associated with even more passion and informative scientific interest.

\section{MUSIC PROJECT (1964-1976) INVOLVING TOMMY BOLIN}

1. DENNY \& THE TRIUMPHS (1964-1965): Tommy Bolin (guitar), Dave Strokes (vocals), Brad Miller (guitars), Steve Bridenbaugh (keyboards), Brad Lavrick (drums), Denny Foote (bass).

2. PATCH OF BLUE (1965-1967): Tommy Bolin (guitar), Dave Strokes (vocals), Brad Miller (guitar), Steve Bridenbaugh (keyboards), Brad Lavrick (drums), Denny Foote (bass) \#1, George Lavrick (bass) \#2.

3. AMERICAN STANDARD (1967-1968): Tommy Bolin (guitar), Jeff Cook (vocals), Michael Lothamer (drums), Terry Knieff (bass).

4. ZEPHYR (1968-1971): Tommy Bolin (guitar), John Faris (keyboards), David Givens (bass), Candy Givens (vocals), Robbie Chamberlin (drums) \#1, Bobby Berge (drums) \#2.
5. ENERGY (1972-1973): Tommy Bolin (guitar), Bobby Berge (drums), Jeremy Steig (flute), John Faris (keyboards) \#1, David Givens (bass) \#1, Candy Givens (vocals) \#1, Tom Stephenson (keyboards) \#2, Stanley Sheldon (bass) \#2, Gary Wilson (vocals) \#2, Jeff Cook (vocals) \#3, Max Gronenthal also as Max Carl (keyboards $\&$ vocals) \#4.

6. Billy Cobham (1973): Billy Cobham (drums), Tommy Bolin (guitars), Lee Sklar (bass), Jan Hammer (keyboards)

7. JAMES GANG (1973-1974): Tommy Bolin (guitar \& vocals), Jimmy «Jim» Fox (drums), Dale Peters (bass), Roy Kenner (vocals), Albhy Galuten (synthesizer) \#2.

8. THE LEGENDARY 4 NIKATORS (1974): Tommy Bolin (guitar), David Givens (bass), Otis Taylor (harp), Candy Givens (vocals).

9. Alphonse Mouzon (1974-1975): Alphonse Mouzon (drums, vocals, keys), Henry Davis (electric bass), Jerry Peters (electric piano, organ), Rocke Grace (keyboards - 9), Tommy Bolin (guitar - solo 2, 3, 7, 8, 9), Jay Graydon (guitar — solo 4), Lee Ritenour (guitar — solo 4, 5, 6), Stanley Sheldon (bass - 9)

10. MOXY (1975): Douglas «Buzz» Sherman (vocals), Earl Johnson (guitar, solo - 2, 3, 7), Terry Juric (bass), Buddy Caine (guitar), Bill Wade (drums), Tommy Bolin (guitar, solo - 1, 4, 5, 6, 7, 8), Tom Stephenson (piano, solo - 01), Buddy Caine (rhythm guitar) \#2.

11. Tommy Bolin (solo) (1975): Tommy Bolin (guitar \& lead vocals), Stanley Sheldon (bass - 1, 2, 3, 5, 6, 7), Paul Stallworth (bass - 4, 8, 9), Dave Foster (piano/ synthesizer - 1, 2, 3), Jan Hammer (synth. - 6, 7, drums - 6), Ron Fransen (piano - 9), David Sanborn (saxophone - 6, 7), Jeff Porcaro (drums - 1, 2, 3, 5), Prairie Prince (drums - 4, 8), Michael Walden (drums 7), Bobbie Berge (drums - 9), Phil Collins (percussion - 4), Sammy Figueroa (percussion - 6, 7), Rafael Cruz (percussion - 6, 7), Dave Brown (background vocals - 1), Lee Kiefer (background vocals - 1), Glenn Hughes (background vocals - 3) \#.

12. DEEP PURPLE (Mk IV) (1975-1976): Tommy Bolin (guitar \& vocals), David Coverdale (vocals), Glenn Hughes (bass \& vocals), Jon Lord (keyboards), lan Paice (drums).

13. THE TOMMY BOLIN BAND (1976): Tommy Bolin (guitars, keyboards, vocals \& piano), Norma Jean Bell (percussion, vocals \& saxophone), Bobbye Hall (percussion), Del Newman (string arrangements), Mark Stein (keyboards \& vocals) \#1, 2, 3, Reggie McBride (bass \& vocals) \#1, Narada Michael Walden (drums \& vocals) \#1, Bobby Berge (drums \& percussion) \#2, Jimmy Halsip (bass) \#2, Johnnie Bolin (drums) \#3, Max Gronenthal (keyboards \& vocals) \#4, Mark Craney (drums) \#4, Carmine Appice (drums - 6).

Tommy Bolin's music history does not end there, as the synthesis of nostalgic trend in recording rock music with innovative approaches has recently become apparent. 
May 11, 2011 in DVD and Blu-Ray formats comes feature-length documentary Phoenix Rising (Full time - 142 minutes), in which Jon Lord and Glenn Hughes set out their views on developments following the departure of Gillan and Glover, and later - and Blackmore. Before the 80-minute documentary part, which is called Gettin' Tighter. The Untold Story of the 1975-1976 Mk IV World Tour and is served in the original English, including with Russian subtitles, this DVD contains Rises Over Japan. A longer version of this release also comes with a CD or two vinyl records, the contents of which are arranged in two previously released CD This Time Around: Live in Tokyo and the King Biscuit Flower Hour Presents: Deep Purple in Concert.

In March 2011, the label «Dismanic Label Group»

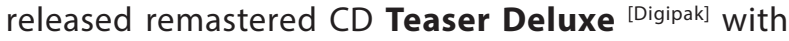
new mixes and a bonus-track of an alternative version of «Crazed Fandango».

One of the latest releases, which should be mentioned, is the album-dedication to Tommy Bolin \& Friends - Great Gypsy Soul, released on March 26, 2012 on the label «429 Records». The album includes new and alternative version of the original material, all the guitar and vocals tracks were performed by Tommy Bolin and his band THE TOMMY BOLIN BAND. In the process of creating a tribute disc Great Gypsy Soul the previously undisclosed Bolin records stored on multitrack tape were used. Manufacturers, leaving intact the structure of tracks with Bolin's vocals and guitar, added new guitar and vocals of guest musicians. Such contemporary musicians as Glenn Hughes, Steve Morse, Peter Frampton, Myles Kennedy, Joe Bonamassa, and others were able to pay «digital» tribute with the use of modern record technologies on each composition.

The out-of-print The Ultimate Tommy Bolin box set was released in 1989, and several tribute albums have followed, including 2012's meek Great Gypsy Soul, which featured guitarists like Derek Trucks and Warren Haynes playing over unreleased Bolin demo tracks, the album a pure studio creation that should be avoided at any cost ${ }^{[20]}$.

We should pay particular attention to the previously unreleased song "Sugar Shack», which is performed by Glenn Hughes on this album. The text was completely written by Tommy Bolin and he made some musical sketches. As a result of Glenn Hughes' improvements a very juicy and brand-new joint composition in memory of a friend has been made. Listening to this $C D$ and his soulful vocals and guitar attacking, we feel the legendary and eternally young Tommy Bolin.

August 2, 2013 was held the next International Festival of requiem, dedicated to Tommy Bolin, which were not only well-known in the world of classic rock musicians and bands, but also a special guest TOMMY BOLIN TRIBUTE BAND by which artistic heri- tage Bolin has found yet another new life. And August 13, 2013 released digipak two CDs entitled Whirlwind (label «Cleopatra Records/Purple Pyramid», L.A.), which represent previously unavailable versions of compositions from various projects with Tommy Bolin. Deluxe Edition includes the $2 \mathrm{CD}$ plus 3 postcards, a Tommy Bolin signature guitar pick (copy), collectible patch and pin. Made only 1000 copies for record collectors.

Pete Pardo wrote in his review of the album: «Much like Jimi Hendrix, the life \& music of guitar legend Tommy Bolin seemed to have crashed and burned all too quickly... And, once again just like Hendrix, since Bolin's death there has been a wealth of live and studio recordings to come out on the market that further prove the talents of this guitar genius» ${ }^{[21]}$. For this review Steven Reid added: "Over the years since his untimely death in 1976, Bolin's live and unreleased work has been continually mined, with some true gems being unearthed in the process and while Whirlwind, the latest set of Bolin rarities, does contain some music already available elsewhere, it still manages to be one of the better sets to boast the late musician's name... Musicians come and go across the two discs and many sessions gathered together here, but unlike most albums which cull together sessions never initially intended for release, the standard remains remarkably high» ${ }^{[21]}$.

John Kindred: «The music on Whirlwind leans more in the direction of Jazz-fusion than straight-up Rock. It is important to stress that the majority of the music here is demos. A lot of the ideas are improvised jams and were the beginning of ideas that hadn't been completely fleshed out»» ${ }^{[22]}$.

In 2014 label «Cleopatra Records/Purple Pyramid» released another interesting 3CD Deluxe Box Set of phonographic Tommy Bolin \& ZEPHYR - The 1969 Debut Album (disc one), The Live Cuts 1969-1973 (disc two), Live At Tulagis (Boulder, CO - June 19, 1973) (disc three).

Just before Bolin's final con cert, Jon Marlowe of the Miami News, after an interview with the guitarist, told him, «Take care of yourself», to which Tommy replied, «I've been taking care of myself my whole life. Don't worry about me, I'm going to be around for a long time» ${ }^{\left[{ }^{[6]}\right.}$. He was buried December $10^{\text {th }}$ in the family plot in Calvary Cemetery in Sioux City.

Rick Bolin says the family only saw one royalty payment after his brother's death. But that may change with Geffen's new release. According to Jeff Cook, who's been in contact with the label, «Geffen has gone to great lengths to make sure the family gets a share of the money» ${ }^{[23]}$. Now, memories and music are the only things left of Tommy Bolin ${ }^{[18]}$.

Bolin's music is elegant and it is characterized by a combination of power and exquisite beauty. Being a pioneer in working with sound, he won recognition 
among jazz and rock musicians at a young age. His death left a void in the sector of definitely unique rock music which is a music mix-cocktail of jazz, hard rock and vintage blues.

Based on the analysis, the main conclusion is obvious: in the 1975-1976 was four errors - branding (the first), communication (the second), psychological (the third) and operational (the fourth), the totality of which played a fatal role ${ }^{[24 ; 25 ; 26]}$.

We have expressed and tried to justify the assumption that a great musician, perhaps one of the most prolific and underrated guitarists of all times, Tommy Bolin has become hostage to the brand which was originally created for the realization of other ideas of another remarkable musician Ritchie Blackmore. You never know if the team and label management listened to David Coverdale's ideas, the events would have developed differently ${ }^{[27 ; 28 ; 29]}$.

Unfortunately, these and some other circumstances were the main determinants of Bolin's addiction. As a result, on December 4, 1976 the musician was found dead in a hotel room in Miami. He was only 25 years old. He was a great talent that will always have a special place in heart many music fans.

And his Great Gypsy Soul is still with us...
In this regard, we see one additional educational task - to attract the attention of the younger generation of music lovers to the creation of Tommy Bolin, whose name, in general, for many years remains a symbol only for a fairly narrow range of rock fans...

Collecting LP-records of great musicians and other artifacts music soundrecording serves different purposes: pragmatic, aesthetic, economic, sacral, research and more. The study of the legal features of various types of editions, recording new interpretations of previously issued press releases and other problems in the area of the right to record and musical citation may be prospects for further research in the «phonographic sector» of intellectual property rights.

And finally the last argument. On May 22, 2015 is scheduled official release of the new album by WHITESNAKE speaking (for the relevant experts and many fans!) called The Purple Album, which is redefining the DEEP PURPLE's heritage from period 1974-1975. In current practice, the producer of the music business like reception with formal legal point called the English phrase «re-imagination of classic songs». On this release taken a lot of songs written and recorded with Tommy Bolin in period Come Taste the Band.

\section{REFERENCES (TRANSLITERATED)}

1. Book Review: Touched By Magic: The Tommy Bolin Story by Greg Prato // Discover The Forest.Org URL: http:// blogcritics.org/books/article/book-review-touched-by-magic-the/.

2. Jisi C. Shooting Star / Chris Jisi, Mark Bosch // Guitar World Magazine, November 1988 URL: http://www. tbolin.com/articles/guitarworld_nov88.html.

3. Prato G. Touched by Magic: The Tommy Bolin Story / Greg Prato._ Perfect-bound Paperback, 2008.— 264 p.

4. Tommy Bolin biography on US radio // The Highway Star: The Original Deep Purple Web Pages. - Sunday, March 31st, 2013 URL: http://www.thehighwaystar.com/news/2009/01/20/tommy-bolin-biography-on-usradio.

5. Robinson S. Rock On Tommy: The Tommy Bolin Story / Simon Robinson (submitted by Wally Zielonka) // Kerrang Magazine No. 26, October 7-26, 1982 URL: http://www.tbolin.com/articles/kerrang_032676.html.

6. Young C. M. Tommy Bolin dead at 25 of overdose / Charles M. Young // Rolling Stones Magazine, Januray 13, 1977.

7. Harper B. Tommy Bolin 'Teaser' / Bill Harper // Cool Album of the Day. - 24 Feb. 2013 URL: http:// coolalbumoftheday.com/?p=28319.

8. The Website of the Deep Purple Appreciation Society URL: http://www.deep-purple.net/tree/tommy-bolin/ tommy-bolin-a.html.

9. Cresenti P. When The Deep Purple Falls / Peter Cresenti (submitted by Damian Phelan) // Sounds Magazine, July 3, 1976 // Tommy Bolin Archives URL: http://www.tbolin.com/articles/sounds_070376.html.

10. Smets E. Tommy Bolin. Voodoo Child / Eric Smets (Français). — Camion blanc (16 octobre 2012). - 218 p.

11. Herdt J. More Tommy Bolin History / John Herdt 2005, 2012 // Tommy Bolin Archives URL: http://www.tbolin. com/history/more.html.

12. Barton G. Road Trippin': The Deep Purple Mark IV Tour / Geoff Barton (Submitted by Wally Z) // Classic Rock Magazine, October 2003 URL: http://www.tbolin.com/articles/classicrock_oct03.html.

13. Come Taste the Band - istoriya sozdaniya al'boma // Armenian Pages DP — 2011 URL: http://www.deeppurple.am/come_taste_the_band.html.

14. Gordon K. A. Blues News Round-Up: Teasing Tommy Bolin / Keith A. Gordon // About.com Guide URL: http:// blues.about.com/b/2012/08/31/blues-news-round-up-teasing-tommy-bolin.htm.

15. The Tommy Bolin Story / Author Unknown (submitted by John Herdt) // Unknown Magazine URL: http:// www.tbolin.com/articles/unknown_magazine.html. 
16. Burger J. Why I Joined Deep Purple / Jeff Burger (submitted by John Herdt) // Creem Magazine, November 1975 URL: http://www.tbolin.com/articles/creem_1175.html.

17. Tommy Bolin: Guitarist / Singer / Songwriter // Tommy Bolin: Memorial Fund [Elektronnyi resurs]. — Rezhim dostupa: http://www.tommybolin-official.com/abouttommybolin.html.

18. Asakawa G. «Shooting Star» - The Rise and Fall of Tommy Bolin / Gil Asakawa // Westword, October 11-17, 1989 URL: http://www.angelfire.com/ny/bolinfan/interviews/gil01.html.

19. Halbert J. Every Home Should Have One: Tommy Bolin Private Eyes (Columbia) / James Halbert (Submitted by Wally Z) // Classic Rock URL: http://www.tbolin.com/articles/classicrock_mar03.html/.

20. Gordon K. A. Tommy Bolin Profile / Keith A. Gordon // About.com Guide URL: http://blues.about.com/od/ artistprofiles/p/Tommy-Bolin-Profile.htm.

21. Reviews - Bolin, Tommy: Whirlwind (Pete Pardo, Steven Reid) // Sea of Teanquility: The Web Sourse for Progressive Rock, Sept. 1st 2013 URL: http://www.seaoftranquility.org/reviews.php?op=showcontent\&id=14879

22. Reviews - Bolin, Tommy: Whirlwind (John Kindred) // HardRockHaven.net URL: http://hardrockhaven.net/ online/2013/09/tommy-bolin-whirlwind-cd-review/

23. Tommy Bolin - The Guitar Man // August 24, 2012 in Classic Rock, Magazines URL: http://trinkelbonker. wordpress.com/2012/08/24/tommy-bolin-the-guitar-man/.

24. Sineokii O.V. Tommi Bolin. Fonograficheskii diskurs i tsifrovaya epitafiya / O. V. Sineokii // Chelovek i kul'tura (NB: Kul'tury i iskusstva).— 2013.— № 1.— S. 166-220.

25. Sineokij O. The Few Lives of Tommy Bolin Record Tapes: Why Was Necessary Rebranding? = Neskol'ko zhiznei zapisei Tommi Bolina: pochemu byl neobkhodim rebreding? / O. Sineokij = O. Sineokii // Scientific Letters of Academic Society of Michal Baludansky (Košice, Slovakia). — Volume 3, No. 3 / 2013. - pp. 158-162.

26. Sineokii O.V. Tommi Bolin i zvukozapisyvayushchie kommunikatsii (al'ternativnaya versiya): [nauchnopublitsisticheskoe esse] = Tommy Bolin \& Record Communications (Alternative Version): [Scientific and Jou rnalistic Essay] / Oleg Sineokii = Oleg Sineokyj. — Košice, Slovakia: Published by Academic Society of Michal Baludansky; Printed by UK TU (Slovak Republic), 2013. - $100 \mathrm{~s}$.

27. Barton Dzh. Net dyma bez ognya / Dzheff Barton // Classic Rock.— 2004.— № 11-12 (34). — S. 52-59.

28. Barton Dzh. V samom serdtse pekla / Dzheff Barton // Classic Rock._ 2009._ № 3 (74). — S. 60-73.

29. Barton Dzh. Prezhde chem nadolgo umolknut' / Dzheff Barton // Classic Rock._ 2011.— № 1-2 (92).— S. 30-34 